\title{
Effects of Colchicine and Vinblastine on the Cellular Action of Vasopressin in Mammalian Kidney
}

\author{
A POSSIBLE ROLE OF MICROTUBULES
}

\author{
Thomas P. Dousa and LARRY D. Barnes \\ From the Nephrology Research Laboratories, Department of Medicine \\ (Division of Nephrology) and Department of Physiology and Biophysics, \\ Mayo Clinic and Foundation, Rochester, Minnesota 55901
}

A в S T R A C T To evaluate the possible role of microtubules in the cellular action of vasopressin on the mammalian kidney, the effects of microtubule-disrupting agents were studied in vivo and in vitro.

In vivo studies were done in rats in mild to moderate water diuresis induced by drinking $5 \%$ glucose. Microtubule-disrupting alkaloids, colchicine $(0.1 \mathrm{mg} /$ day $)$ or vinblastine $(0.08 \mathrm{mg} /$ day $)$, given intraperitoneally, did not change water and solute excretion itself, but blocked or markedly inhibited the antidiuretic response (increase in urine osmolality and decrease in urine flow) to exogenous vasopressin. Total solute excretion was unaffected by these two alkaloids and there were no substantial changes in excretion of sodium, potassium, or creatinine. Lumicolchicine, a derivative of colchicine that does not interact with microtubules, did not alter the antidiuretic response to exogenous vasopressin. Activities of adenylate cyclase in the renal medullary plasma membrane, and cyclic AMP phosphodiesterase and protein kinase in renal medullary cytosol, were not influenced by $10^{-8}-10^{-4} \mathrm{M}$ colchicine or vinblastine in vitro. Studies on the subcellular distribution of microtubular protein (assessed as $\left[{ }^{8} \mathrm{H}\right]$ colchicine-binding protein) in renal medulla shows that this protein is contained predominantly in the cytosol. Particulate fractions, including plasma membrane, contain only a minute amount (less than $6 \%$ ) of the colchicine-binding activity.

This work was presented at the meeting of the Western Section of the American Federation for Clinical Research in Carmel, California in February, 1974. (Clin. Res. 22: 206A, 1974).

Dr. Dousa is an Established Investigator of the American Heart Association. Dr. Barnes is the recipient of a Mayo Research Fellowship.

Received for publication 21 November 1973 and in revised form 28 January 1974.
The results suggest that the integrity of cytoplasmic microtubules in cells of the distal nephron is required for the antidiuretic action of vasopressin, probably in the sites distal to cyclic AMP generation in the mammalian kidney.

\section{INTRODUCTION}

The mechanism by which vasopressin regulates water permeability of certain epithelial membranes is only partially known. Considerable evidence accumulated in recent years indicates that cyclic AMP serves as an intracellular mediator in the cellular action of vasopres$\sin (1,2)$. The mechanism by which cyclic AMP formed under the influence of vasopressin increases water permeability of collecting ducts remains unknown. Still hypothetical is the idea that cyclic AMP acts on the lumenal plasma membrane through its influence on protein phosphorylation (3-5). Taylor, Mamelak, Raven, and Maffly (6) found that some drugs known to disrupt the structure of microtubules partially inhibit the increase in water permeability in response to vasopressin and exogenous cyclic AMP in isolated toad urinary bladders. The stimulatory effect of vasopressin and cyclic AMP on active sodium transport in the same tissue was not influenced by these drugs. This suggests that microtubules are involved in the regulation of water permeability by vasopressin in steps subsequent to the cyclic AMP formation.

The regulatory effect of vasopressin on water permeability of the distal nephron in the mammalian kidney appears to be analogous to the amphibian urinary bladder system, including the mediatory role of cyclic AMP $(1,2)$. The presence of microtubules in cells of collecting ducts has been described (7). 
In the present study, colchicine and vinblastine, two microtubule-disrupting agents (8), blocked the antidiuretic effect of exogenous vasopressin in mammalian kidney. Colchicine or vinblastine did not inhibit adenylate cyclase, cyclic AMP phosphodiesterase, or cyclic AMPdependent protein kinase in subcellular fractions from renal medulla. The results support the view that microtubules play a role in the cellular action of vasopressin in steps distal to cyclic AMP formation in the mammalian kidney.

\section{METHODS}

Materials. $\left[{ }^{8} \mathrm{H}\right]$ colchicine and $\left[{ }^{3} \mathrm{H}\right]$ cyclic AMP were products of New England Nuclear, Boston, Mass. [ $\left.{ }^{2} \mathrm{P}\right] \alpha-$ ATP and [ $\left.{ }^{2} \mathrm{P}\right] \boldsymbol{\gamma}$-ATP were products of ICN Corp., Chemical \& Radioisotopes Div., Irvine, Calif. All chemicals and biochemicals used were of highest purity grades. Nonradioactive colchicine and vinblastine were gifts of Eli Lilly \& Co., Indianapolis, Ind. For in vitro stimulation of adenylate cyclase, synthetic [8-arginine]-vasopressin, Sigma Chemical Co., St. Louis, Mo., was employed. In animal experiments, vasopressin tannate (Pitressin tannate in oil, Parke Davis $\&$ Co., Detroit, Mich.) was used. The dose of $0.5 \mathrm{U}$ was shown to elicit supramaximal antidiuretic effect in rats (9). Lumicolchicine was prepared by irradiation of colchicine with a long wavelength ultraviolet lamp as described by Mizel and Wilson (10). Measurement of the decreased absorbancy at $350 \mathrm{~nm}$ in $100 \%$ ethanol established the conversion of colchicine to lumicolchicine. The ethanol was evaporated under a stream of nitrogen and the lumicolchicine was dissolved for injection into animals.

In vivo methods. The effect of colchicine, vinblastine, and lumicolchicine on the action of vasopressin in vivo was studied in adult male rats of Sprague-Dawley strain weighing 250-300 g. Body weight was measured daily and did not change significantly during the experimental period either in control animals or in animals receiving studied drugs. The animals were allowed to adjust to individual metabolic cages for several days before the experiment. The animals were kept in air-conditioned animal rooms with a temperature of $25^{\circ} \mathrm{C}$ and were fed dry food ad lib (Purina Laboratory Chow, Ralston Purina Co., St. Louis, Mo.). Mild to moderate water diuresis was induced in rats by feeding $5 \%$ glucose (11). Animals developed diuresis of different degrees, which was nevertheless relatively constant in each individual animal. Therefore, based on observations from control periods durng the first two days, in each experiment the animals were divided into two groups having, on the average, a similar degree of diuresis. On days $3-6$, one group of animals served as a control and received solvent without drugs, while the other group, experimental, received the test drugs. On days $4-6$, both groups received the same dose of vasopressin. The animals receiving the indicated doses of colchicine, vinblastine, or lumicolchicine did not show any apparent clinical signs of toxicity. No diarrhea was observed. The urines were collected daily under mineral oil and qualitatively examined for the presence of glucose and protein ${ }^{1}$; no glucosuria or proteinuria was detected. No change in urinary excretion of creatinine or in serum creatinine concentration was de-

${ }^{1}$ The glucose was determined with Clinitest and protein was estimated with Albustix Reagent Strips, Ames Co., Div. of Miles Lab., Inc., Elkhart, Ind. tected after administration of alkaloids (Tables I and III). At termination of in vivo experiments, animals were sacrificed and the abdominal cavity was opened and macroscopically examined. No signs of ascites or other macroscopic pathological changes were observed. Kidneys were cut coronally and inspected macroscopically. No differences in either cortical or medullary tissues were observed between control and experimental animals.

Additional experiments were conducted to test for nonspecific toxic effects of colchicine. A group of five rats was treated with colchicine, as described in Table I and compared with the same number of control animals. No difference was observed between control and colchicine-treated rats in levels of serum creatinine, blood urea nitrogen, calcium, potassium, sodium, or in urinary $\mathrm{pH}$ measured at the end of experiment. Kidneys were examined histologically and no pathological changes were observed in glomeruli, tubuli, or other renal structures. In another control experiment, animals were again treated with the colchicine as described in Table $I$ and the drug was then discontinued for 3 days. After this rest period, the rats were injected with exogenous vasopressin. The animals treated previously with colchicine did not differ in the antidiuretic response from the control animals. Urine osmolality $\left(U_{0 s m}\right)^{8}$ was measured with a Fiske osmometer (Fiske Associates, Inc., Uxbridge, Mass.), and sodium ( $U_{\mathrm{Na}}$ ) and potassium ( $\mathrm{U}_{\mathbf{K}}$ ) were determined with a Technicon Autoanalyzer II (Technicon Instruments Corp., Tarrytown, N. Y.). Urinary and serum creatinine was measured spectrophotometrically (12). 24-h urinary output (urine flow), total solute excretion

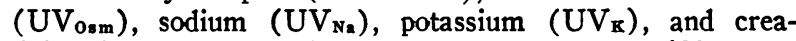
tinine $\left(U_{\left.V_{C_{r}}\right)}\right.$ were calculated and expressed per 100 grams of body weight. Colchicine, vinblastine, and lumicolchicine were dissolved in a solution of $70 \mathrm{mM} \mathrm{NaCl}$ and $5 \mathrm{mM}$ Tris- $\mathrm{HCl}, \mathrm{pH} \mathrm{7.4,} \mathrm{for} \mathrm{intraperitoneal} \mathrm{injections.} \mathrm{Each} \mathrm{in-}$ dividual dose of drugs was contained in $0.2 \mathrm{ml}$ of solvent, and control animals received the same volume of solvent without drug.

Dosages of alkaloids utilized in the present study were based on estimation from other studies (13) and preliminary experiments. Dosages lower than those employed in present experiments produced no or only borderline effect.

In vitro methods. The content of microtubular protein was determined by utilizing its ability to bind colchicine specifically (8). The colchicine-binding protein was assayed by the method described by Weisenberg, Borisy, and Taylor (14) with DEAE filter paper disks. When particulate fractions of renal medullary homogenate were studied and compared with soluble proteins, double-layer disks of DEAE cellulose paper and GF/C Whatman glass fiber papers were used to assure retention of membrane fragments. GF/C glass fiber paper itself retained neither $\left[{ }^{3} \mathrm{H}\right]$ colchicine nor colchicine-binding protein. The tissue extracts were incubated with $0.6 \times 10^{-6} \mathrm{M}\left[{ }^{8} \mathrm{H}\right]$ colchicine $\left(10^{6} \mathrm{cpm} /\right.$ tube) at $37^{\circ} \mathrm{C}$, in $0.3 \mathrm{ml}$ of a buffer containing $10 \mathrm{mM}$ $\mathrm{MgCl}_{2}, 10 \mathrm{mM}$ potassium phosphate, and $5 \times 10^{-5} \mathrm{M}$ EDTA $(\mathrm{pH} 6.8)$. The radioactivity of $\left[{ }^{3} \mathrm{H}\right]$ colchicine retained in filters was counted in Bray's solution.

Adenylate cyclase was assayed by the method described in our previous study (15). For the chromatographic separation of cyclic AMP from other nucleotides, we used a modification described recently (16).

'Abbreviations used in this paper: $\mathrm{Cr}$, creatinine; GFR, glomerular filtration rate; Uosm, urine osmolality; UV, total solute excretion.

Microtubules in the Action of Vasopressin 
TABLE I

Inhibition of Renal Response to Vasopressin by Colchicine

\begin{tabular}{|c|c|c|c|c|c|c|c|}
\hline , & & Day 1 & Day 2 & Day 3 & Day 4 & Day 5 & Day 6 \\
\hline $\begin{array}{l}\text { Urine flow, } m l / 100 \mathrm{~g} \text { body } w t \\
\text { per } 24 h \pm \mathrm{SEM}\end{array}$ & $\begin{array}{l}\text { Control } \\
\text { Experimental } \\
P \text { value* }^{*}\end{array}$ & $\begin{array}{l}16.4 \\
\pm 2.65 \\
20.65 \\
\pm 3.61 \\
\text { NS }\end{array}$ & $\begin{array}{l}24.07 \\
\pm 4.93 \\
19.24 \\
\pm 5.06 \\
\text { NS }\end{array}$ & $\begin{array}{l}20.55 \\
\pm 5.44 \\
19.35 \\
\pm 4.97 \\
\text { NS }\end{array}$ & $\begin{array}{r}5.42 \\
\pm 0.55 \\
21.16 \\
\pm 5.55 \\
<0.02\end{array}$ & $\begin{array}{r}4.50 \\
\pm 0.42 \\
20.41 \\
\pm 4.97 \\
<0.01\end{array}$ & $\begin{array}{r}4.40 \\
\pm 0.33 \\
18.77 \\
\pm 4.23 \\
<0.01\end{array}$ \\
\hline $\mathrm{U}_{\mathrm{Osm}}$, mosmol/kg $\mathrm{H}_{2} \mathrm{O} \pm S E M$ & $\begin{array}{l}\text { Control } \\
\text { Experimental } \\
P \text { value }\end{array}$ & $\begin{array}{r}657 \\
\pm 89 \\
586 \\
\pm 126 \\
\mathrm{NS}\end{array}$ & $\begin{array}{r}533 \\
\pm 163 \\
745 \\
\pm 201 \\
\mathrm{NS}\end{array}$ & $\begin{array}{r}640 \\
\pm 189 \\
724 \\
\pm 210 \\
\text { NS }\end{array}$ & $\begin{array}{c}1,466 \\
\pm 69 \\
684 \\
\pm 225 \\
<0.01\end{array}$ & $\begin{array}{l}1,707 \\
\pm 101 \\
\quad 688 \\
\pm 222 \\
\quad<0.005\end{array}$ & $\begin{array}{c}1,717 \\
\pm 96 \\
722 \\
\pm 212 \\
<0.005\end{array}$ \\
\hline $\begin{array}{l}\mathrm{UV}_{\text {Osm }}, \mu o s m o l / 100 \mathrm{~g} \text { body } w t \\
\quad \text { per } 24 h \pm S E M\end{array}$ & $\begin{array}{l}\text { Control } \\
\text { Experimental } \\
P \text { value }\end{array}$ & $\begin{array}{r}9,773 \\
\pm 841 \\
9,019 \\
\pm 487 \\
\text { NS }\end{array}$ & $\begin{array}{r}9,260 \\
\pm 946 \\
9,907 \\
\pm 487 \\
\text { NS }\end{array}$ & $\begin{array}{r}8,730 \\
\pm 974 \\
9,348 \\
\pm 402 \\
\text { NS }\end{array}$ & $\begin{array}{r}7,772 \\
\pm 511 \\
8,865 \\
\pm 686 \\
\text { NS }\end{array}$ & $\begin{array}{r}7,528 \\
\pm 500 \\
9,041 \\
\pm 721 \\
\text { NS }\end{array}$ & $\begin{array}{r}7,443 \\
\pm 490 \\
9,439 \\
\pm 797 \\
\text { NS }\end{array}$ \\
\hline $\begin{array}{l}\mathrm{UV}_{\mathrm{Na}}, \mu e q N a / 100 \mathrm{~g} \text { body } w t \\
\quad \text { per } 24 h \pm S E M\end{array}$ & $\begin{array}{l}\text { Control } \\
\text { Experimental } \\
P \text { value }\end{array}$ & $\begin{array}{r}920 \\
\pm 54 \\
859 \\
\pm 20 \\
\text { NS }\end{array}$ & $\begin{array}{r}907 \\
\pm 43 \\
897 \\
\pm 43 \\
\text { NS }\end{array}$ & $\begin{array}{r}622 \\
\pm 45 \\
764 \\
\pm 86 \\
\mathrm{NS}\end{array}$ & $\begin{array}{c}616 \\
\pm 16 \\
914 \\
\pm 67 \\
<0.005\end{array}$ & $\begin{array}{r}688 \\
\pm 76 \\
737 \\
\pm 68 \\
\quad \mathrm{NS}\end{array}$ & $\begin{array}{r}664 \\
\pm 53 \\
697 \\
\pm 85 \\
\quad \mathrm{NS}\end{array}$ \\
\hline $\begin{array}{l}\mathrm{UV}_{\mathrm{K}}, \mu e q \mathrm{~K} / 100 \mathrm{~g} \text { body } \\
\text { wt per } 24 h \pm S E M\end{array}$ & $\begin{array}{l}\ddagger \text { Control } \\
\ddagger \text { Experimental } \\
P \text { value }\end{array}$ & $\begin{array}{c}1,324 \\
\pm 68 \\
990 \\
\pm 65 \\
<0.01\end{array}$ & $\begin{array}{r}1,404 \\
\pm 73 \\
1,461 \\
\pm 108 \\
\mathrm{NS}\end{array}$ & $\begin{array}{r}1,211 \\
\pm 102 \\
1,372 \\
\pm 125 \\
\mathrm{NS}\end{array}$ & $\begin{array}{l}1,043 \\
\pm 70 \\
1,364 \\
\pm 57 \\
<0.01\end{array}$ & $\begin{array}{c}924 \\
\pm 83 \\
1,385 \\
\pm 82 \\
<0.005\end{array}$ & $\begin{array}{c}910 \\
\pm 63 \\
1,315 \\
\pm 123 \\
<0.2\end{array}$ \\
\hline $\begin{array}{l}\mathrm{UV}_{\mathrm{Cr}} m g / 100 \mathrm{~g} \text { body wt per } \\
\quad 24 h \pm S E M\end{array}$ & $\begin{array}{l}\text { Control } \\
\text { Experimental } \\
P \text { value }\end{array}$ & $\begin{aligned} 7.05 \\
\pm 0.35 \\
6.20 \\
\pm 0.26 \\
\mathrm{NS}\end{aligned}$ & $\begin{array}{r}6.42 \\
\pm 0.47 \\
8.09 \\
\pm 0.47 \\
\mathrm{NS}\end{array}$ & $\begin{array}{r}5.63 \\
\pm 0.20 \\
6.31 \\
\pm 0.47 \\
\text { NS }\end{array}$ & $\begin{array}{c}5.84 \\
\pm 0.18 \\
7.26 \\
\pm 2.12 \\
\mathrm{NS}\end{array}$ & $\begin{array}{r}6.35 \\
\pm 0.70 \\
7.58 \\
\pm 0.71 \\
\text { NS }\end{array}$ & $\begin{array}{r}6.00 \\
\pm 0.47 \\
6.83 \\
\pm 0.48 \\
\mathrm{NS}\end{array}$ \\
\hline
\end{tabular}

* For significance of the difference between control and experimental groups. NS denotes $P>0.05$ ( $t$ test).

¥ There were no significant changes in $U V_{K}$ between consecutive days in either control or experimental groups of animals $(P>0.05$, paired $t$ test), with the exception between days 1 and 2 for the experimental group.

Rats from experimental group received $0.1 \mathrm{mg}$ colchicine intraperitoneally on days $3,4,5$, and 6 ; the control group received only solvent. On days 4,5 , and 6 both groups were administered $0.5 \mathrm{U}$ of pitressin tannate in oil subcutaneously. Each group consisted of six rats. At the end of experiment serum creatinine levels in control and experimental group were $0.789 \pm 0.059$ and $0.727 \pm 0.038 \mathrm{mg} / 100 \mathrm{ml} \pm \mathrm{SEM}$, respectively. These values were not significantly different from each other $(t$ test).

Cyclic AMP phosphodiesterase was assayed by the method described in another of our studies (17). None of the tested drugs interfered with the breakdown of 5 -AMP to nucleosides and phosphate by snake venom $5^{\prime}$-nucleotidase. For the assay of cyclic AMP-dependent protein kinase, we used the same method as in our earlier experiments (4) with the exception that the initial trichloroacetic acid (TCA) precipitate was dissolved in $0.1 \mathrm{ml}$ of $1 \mathrm{~N} \mathrm{NaOH}$ and reprecipitated by 5\% TCA before the final washing on Millipore filters (Millipore Corp., Bedford, Mass.). All assays were run in triplicate.

In studies on subcellular localization of colchicine-binding protein, the fractions were prepared from bovine kidney medulla. All preparations were done at $0-2^{\circ} \mathrm{C}$. The preparation of plasma membranes followed in principle the method described by Fitzpatrick, Davenport, Forte, and Landon (18) except for the following modification: all solutions contained $10 \mathrm{mM} \mathrm{MgCl}, 10 \mathrm{mM}$ potassium phosphate, $2 \times$ $10^{-4} \mathrm{M}$ GTP and $5 \times 10^{-6} \mathrm{M}$ EDTA, and were adjusted to $\mathrm{pH}$ 6.8. These conditions stabilize colchicine-binding protein (19). Other subcellular fractions were prepared as follows: The pellet from the first centrifugation in the above-mentioned modified procedure was resuspended in $2 \mathrm{M}$ sucrose, centrifuged at $13,000 \mathrm{~g}$ for $10 \mathrm{~min}$, and the pellet was taken as the "nuclear" fraction. The supernate from the first centrifugation in the above-mentioned modified 
procedure for plasma membrane preparation was further centrifuged for $20 \mathrm{~min}$ at $10,000 \mathrm{~g}$. The sediment was resuspended in homogenizing medium and recentrifuged as before. The resulting pellet represented the "mitochondrial" fraction. The supernate from the first centrifugation at $10,000 \mathrm{~g}$ for $20 \mathrm{~min}$ was further centrifuged at $100,000 \mathrm{~g}$ for $60 \mathrm{~min}$ and the supernate was taken as the "cytosol." The sediment was resuspended in homogenizing medium and centrifuged again at $100,000 \mathrm{~g}$ for $60 \mathrm{~min}$ and the pellet was then taken as the "microsomal" fraction. The fractions were quickly frozen in dry ice and kept in dry ice until assayed for colchicine-binding activity. Fractions for studies of adenylate cyclase, cyclic AMP phosphodiesterase, and protein kinase activities were prepared in a slightly different way. The plasma membrane fraction was prepared according to the method of Fitzpatrick et al. (18) as employed in our previous studies (4). The supernate from the first centrifugation in this procedure was further centrifuged for $60 \mathrm{~min}$ at $100,000 \mathrm{~g}$, and the supernate (cytosol) was used as a source of protein kinase and cyclic AMP phosphodiesterase activities. The protein content in preparations was determined by the method of Lowry, Rosebrough, Farr, and Randall (20). Radioactivity was determined by liquid scintillation counting. Student's $t$ test was used for statistical evaluation of results for both group and paired comparisons (21).

\section{RESULTS}

\section{In vivo studies}

Effect of colchicine. The effect of colchicine was tested on 12 rats divided into two equal groups. The first 2 days were the control period, and on the 3rd day the experimental group received $0.1 \mathrm{mg}$ of colchicine intraperitoneally divided into two daily doses. On the 4th, 5 th, and 6 th days the experimental group received the same dose of colchicine as on the 3rd day, and both control and experimental groups received $0.5 \mathrm{U}$ of Pitressin subcutaneously. The administration of colchicine itself (day 3) did not produce any change in urine flow Uosm, (Fig. 1) UVosm, sodium, potassium, or creatinine excretion (Fig. 1 and Table I). As expected, the control group responded to exogenous vasopressin by a marked increase in Uosm (Fig. 1) and a corresponding decrease in urine flow, which continued for 2 subsequent days. On the other hand, the same dose of vasopressin did not change Uosm (Fig. 1) and urine flow in animals treated with colchicine either on the 4th or on the following experimental days. Despite a striking difference in the response to exogenous vasopressin in water excretion parameters (Uosm and urine flow) there were no significant differences between control and experimental groups in UVosm or UVor (Table I and Fig. 1). The serum concentration of creatinine, measured at the end of experiment, was not different between control and colchicine-treated groups (Table I). With the exception of a slight increase in sodium excretion in experimental animals on day 4, there was no difference in $U V_{\mathrm{Na}}$ between control and experimental animals. Colchicine does not increase potassium excretion. The apparent differ-

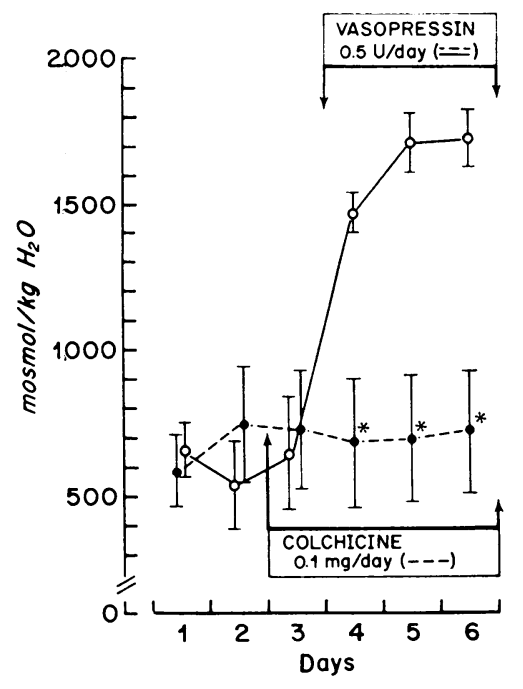

Figure 1 Response of urine osmolality to vasopressin in control rats $(\mathrm{O}-\mathrm{O})$ and in rats treated with colchicine on 3-6 experimental days $(---\bullet)$. Each group consisted of six animals. * value significantly different from controls at $P<0.05$ or more ( $t$ test).

ences in UVк on days 4-6 between the two groups are due to a decrease in potassium excretion in controls rather than to any change in the experimental group.

The effect of lumicolchicine was tested in the same manner described for colchicine. This derivative, given at the same dosage as colchicine, $(0.1 \mathrm{mg} / \mathrm{day})$, had no blocking effect on the antidiuretic response to exogenous vasopressin in terms of an increase in Uosm and a decrease in urine flow (Table II).

Effect of vinblastine. The effect of vinblastine was evaluated in an experiment like that for colchicine, as described above, except that only five rats were used per group. Vinblastine sulfate was administered intraperitoneally to rats in the experimental group on days 3,4 , 5 , and 6 in a single daily dose of $0.08 \mathrm{mg}$. Results are summarized in Table III and Fig. 2. Vasopressin on the 4th day produced only a very small decrease in urine flow and a slight increase in Uosm (Fig. 2) in animals on vinblastine, while controls developed marked antidiuresis. This increase in Uosm $(+\Delta 317 \pm 55$ mosmol $\pm \mathrm{SE})$ in experimental group was much less than in the control group $(+\Delta 1,057 \pm 200$ mosmol $\pm S E$ ) and difference between magnitude of the responses in these two groups was significant at $P<0.025$. Moreover, on the following days (5th and 6 th), while still receiving the same dose of vasopressin, the $\mathrm{U}_{\mathrm{osm}}$ in the experimental group dropped (Fig. 2), urine flow (Table III) increased, and the difference in these parameters between control and experimental group increased further. There were no significant differences between the two groups in UVosm or in serum creatinine measured at the end of experiment (Table III). Vinblastine did not increase the ex-

Microtubules in the Action of Vasopressin

255 
TABLE II

Failure of Lumicolchicine to Influence Renal Response to Vasopressin

\begin{tabular}{|c|c|c|c|c|c|c|c|}
\hline & & Day 1 & Day 2 & Day 3 & Day 4 & Day 5 & Day 6 \\
\hline $\begin{array}{l}\text { Urine flow, } m l / 100 \mathrm{~g} \text { body } w t \\
\text { per } 24 h \pm S E M\end{array}$ & $\begin{array}{l}\text { Control } \\
\text { Experimental }\end{array}$ & $\begin{array}{c}18.28 \\
\pm 3.08 \\
17.12 \\
\pm 3.50\end{array}$ & $\begin{array}{r}19.72 \\
\pm 4.72 \\
16.80 \\
\pm 2.62\end{array}$ & $\begin{array}{r}24.59 \\
\pm 4.60 \\
24.05 \\
\pm 5.13\end{array}$ & $\begin{array}{c}4.18^{*} \\
\pm 0.47 \\
3.84^{*} \\
\pm 0.72\end{array}$ & $\begin{array}{r}4.76 \\
\pm 0.37 \\
4.12 \\
\pm 0.61\end{array}$ & $\begin{array}{r}5.39 \\
\pm 0.48 \\
4.82 \\
\pm 0.64\end{array}$ \\
\hline $\mathrm{U}_{\mathrm{Osm}} \mathrm{mosmol} / \mathrm{kg} \mathrm{H}_{2} \mathrm{O} \pm S E M$ & $\begin{array}{l}\text { Control } \\
\text { Experimental }\end{array}$ & $\begin{array}{r}496 \\
\pm 106 \\
590 \\
\pm 129\end{array}$ & $\begin{array}{r}510 \\
\pm 123 \\
532 \\
\pm 132\end{array}$ & $\begin{array}{r}434 \\
\pm 100 \\
445 \\
\pm 129\end{array}$ & $\begin{array}{l}1,322^{\ddagger} \\
\pm 21 \\
1,473^{\ddagger} \\
\pm 167\end{array}$ & $\begin{array}{l}1,421 \\
\pm 104 \\
1,436 \\
\pm 163\end{array}$ & $\begin{array}{l}1,370 \\
\pm 156 \\
1,450 \\
\pm 158\end{array}$ \\
\hline
\end{tabular}

* Urine flow decreased in response to vasopressin from day 3 to day 4 in both control and experimental groups $(\Delta 20.41 \pm 4.68$ and $\Delta 20.21 \pm 4.56$, respectively). These decreases were both significant $(P<0.01)$ but not significantly different from each other.

$\ddagger \mathrm{U}_{\mathrm{Oam}}$ increased in response to vasopressin from day 3 to day 4 in both control and experimental groups $(\Delta 888 \pm 108$ and $\Delta 1,028 \pm 74 \mathrm{mosmol} / \mathrm{kg} \mathrm{H}_{2} \mathrm{O}$, respectively). The increases in both groups were significant $(P<0.001)$ but not significantly different from each other.

Rats from experimental group received $0.1 \mathrm{mg}$ of lumicolchicine on days 3, 4, 5, and 6; control group received only solvent. On days 4,5 , and 6 both groups received $0.5 \mathrm{U}$ of Pitressin tannate in oil subcutaneously. Number of animals in each group was six. There were no significant differences in urine flow or $\mathrm{U}_{0 s m}$ between groups in any experimental day.

cretion of either sodium or potassium. The apparent differences in UV $\mathrm{Na}_{\mathbf{N a}}$ and UVx on days 4-6 are due to decreased excretion of sodium and potassium in controls rather than an increased excretion in experimental animals.

\section{In vitro studies}

Cyclic AMP metabolism. The effects of vinblastine and colchicine on the plasma membrane adenylate cyclase and cytosolic cyclic AMP phosphodiesterase were

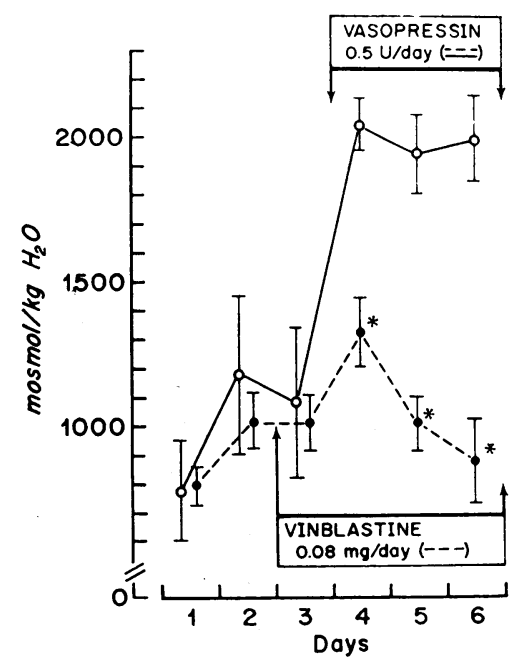

Figure 2 Response of urine osmolality to vasopressin in control rats $(\mathrm{O}-\mathrm{O})$ and in rats treated with vinblastine on 3-6 experimental days $(---)$. Each group consisted of five animals. * values significantly different from controls at $P<0.05$ or more ( $t$ test). evaluated in preparations from bovine renal medulla. Basal or vasopressin-stimulated adenylate cyclase activity was not inhibited by colchicine or vinblastine (Table IV). Since, as shown below, binding of colchicine to proteins is a rather slow process (Fig. 3 ), the cytosol was incubated with either colchicine or vinblastine for $60 \mathrm{~min}$ before the assay for cyclic AMP phosphodiesterase. No change in cyclic AMP phosphodiesterase activity was observed due to preincubation with these two drugs (Table IV).

Protein kinase. Protein kinase was assayed in cytosol and the effects of preincubation with colchicine and vinblastine (similar to the experiments with cyclic AMP

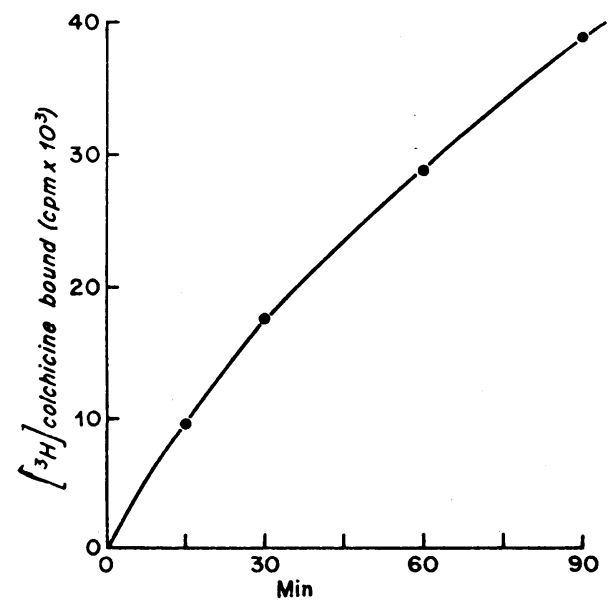

FIGURE 3 Time-course of the binding of $\left[{ }^{3} \mathrm{H}\right]$ colchicine to the proteins of renal medullar cytosol. Protein content was $87 \mu \mathrm{g} / \mathrm{tube}$; for incubation conditions see Methods. 
TABLE III

Inhibition of the Renal Response to Vasopressin by Vinblastine

\begin{tabular}{|c|c|c|c|c|c|c|c|}
\hline & & Day 1 & Day 2 & Day 3 & Day 4 & Day 5 & Day 6 \\
\hline \multirow{5}{*}{$\begin{array}{l}\text { Urine flow, } m l / 100 \mathrm{~g} \text { body } w t \\
\quad \text { per } 24 h \pm S E M\end{array}$} & \multirow[t]{2}{*}{ Control } & 9.45 & 9.11 & 9.22 & 3.52 & 3.62 & 3.11 \\
\hline & & \pm 1.87 & \pm 1.69 & \pm 1.96 & \pm 0.21 & \pm 0.37 & \pm 0.28 \\
\hline & \multirow[t]{2}{*}{ Experimental } & 10.21 & 8.63 & 8.06 & 6.15 & 7.78 & 9.21 \\
\hline & & \pm 1.75 & \pm 1.48 & \pm 1.34 & \pm 0.38 & \pm 1.57 & \pm 1.54 \\
\hline & $P$ value* & NS & NS & NS & $<0.001$ & $<0.02$ & $<0.005$ \\
\hline \multirow[t]{5}{*}{$\mathrm{U}_{\mathrm{Osm}}, \mathrm{mosmol} / \mathrm{kg} \mathrm{H}_{2} \mathrm{O} \pm S E M$} & \multirow[t]{2}{*}{ Control } & 778 & 1,176 & 1,080 & 2,137 & 1,946 & 1,989 \\
\hline & & \pm 179 & \pm 268 & \pm 262 & \pm 89 & \pm 139 & \pm 151 \\
\hline & \multirow[t]{2}{*}{ Experimental } & 792 & 1,011 & 1,006 & 1,323 & 1,003 & 878 \\
\hline & & \pm 77 & \pm 84 & \pm 95 & \pm 119 & \pm 98 & \pm 146 \\
\hline & $P$ value & NS & NS & NS & $<0.001$ & $<0.001$ & $<0.001$ \\
\hline \multirow{5}{*}{$\begin{array}{l}\mathrm{UV}_{\text {Osm, }} \mu \text { osmol } / 100 \mathrm{~g} \text { body } w t \\
\quad \text { per } 24 h \pm S E M\end{array}$} & \multirow[t]{2}{*}{ Control } & 6,241 & 9,585 & 8,051 & 7,456 & 6,878 & 6,045 \\
\hline & & \pm 955 & $\pm 1,764$ & \pm 527 & \pm 284 & \pm 451 & \pm 416 \\
\hline & \multirow[t]{2}{*}{ Experimental } & 7,625 & 8,362 & 7,670 & 7,977 & 7,447 & 7,372 \\
\hline & & \pm 866 & \pm 966 & \pm 509 & \pm 319 & \pm 876 & \pm 802 \\
\hline & $P$ value & $\mathrm{NS}$ & NS & NS & NS & NS & NS \\
\hline \multirow{5}{*}{$\begin{array}{l}\mathrm{UV}_{\mathrm{Na}}, \mu e q K / 100 \mathrm{~g} \text { body } w t \\
\quad \text { per } 24 h \pm S E M\end{array}$} & \multirow[t]{2}{*}{ Control } & 588 & 611 & 760 & 638 & 635 & 523 \\
\hline & & \pm 58 & \pm 45 & \pm 40 & \pm 38 & \pm 49 & \pm 38 \\
\hline & \multirow[t]{2}{*}{ Experimental } & 648 & 752 & 747 & 787 & 775 & 786 \\
\hline & & \pm 50 & \pm 53 & \pm 47 & \pm 79 & \pm 25 & \pm 123 \\
\hline & $P$ value & $\mathrm{NS}$ & NS & NS & $<0.02$ & $<0.05$ & NS \\
\hline \multirow{5}{*}{$\begin{array}{l}\mathrm{UV}_{\mathrm{K}}, \mu e q K / 100 \mathrm{~g} \text { body } w t \\
\quad \text { per } 24 h \pm S E M\end{array}$} & \multirow[t]{2}{*}{$\ddagger$ Control } & 919 & 1,007 & 1,153 & 774 & 709 & 673 \\
\hline & & \pm 45 & \pm 115 & \pm 48 & \pm 42 & \pm 84 & \pm 66 \\
\hline & \multirow[t]{2}{*}{$\ddagger$ Experimental } & 1,073 & 1,187 & 1,298 & 1,207 & 1,274 & 1,317 \\
\hline & & \pm 52 & \pm 43 & \pm 45 & \pm 44 & \pm 69 & \pm 184 \\
\hline & $P$ value & $\mathrm{NS}$ & NS & $\mathrm{NS}$ & $<0.005$ & $<0.02$ & $<0.05$ \\
\hline \multirow{2}{*}{$\begin{array}{l}\mathrm{UV}_{\mathrm{Cr}}, m g / 100 \mathrm{~g} \text { body } w t \\
\quad \text { per } 24 \mathrm{~h} \pm S E M\end{array}$} & \multirow[t]{2}{*}{ Experimental } & $5.27 \S$ & 5.48 & 4.70 & 5.44 & 6.57 & 4.55 \\
\hline & & \pm 0.32 & \pm 0.48 & \pm 0.70 & \pm 1.07 & \pm 0.29 & \pm 0.96 \\
\hline
\end{tabular}

* For significance of the difference between control and experimental groups, NS denotes $P>0.05$ ( $t$ test).

$\ddagger$ There were no significant changes in $\mathrm{UV}_{\mathrm{K}}$ between consecutive days ${ }^{*} P>0.05$, paired $t$ test); except between days 3 and 4 for the control group.

$\S U_{V_{\mathrm{Cr}}}$ value for control group was $5.06 \pm 0.37$.

Rats in experimental groups received $0.08 \mathrm{mg}$ vinblastine intraperitoneally on days 3-6; controls received only solvent. On days 4- 6 both control and experimental were injected with $0.5 \mathrm{U}$ of pitressin tannate in oil subcutaneously. Each group consisted of five rats. At the end of experiment, serum creatinine levels in control and experimental animals were $1.118 \pm 0.110$ and 1.124 $\pm 0.041 \mathrm{mg} / 100 \mathrm{ml}, \pm \mathrm{SEM}$. These values were not significantly different from each other $(t$-test).

phosphodiesterase) were studied (Table V). Both colchicine and vinblastine produced a very small decrease in the enzyme activities when the cytosolic proteins (endogenous substrate) themselves served as a substrate for phosphorylation or when added histones were used as a substrate (Table V).

Subcellular distribution of colchicine-binding protein. Colchicine binds to cellular proteins from renal medulla, indicating the presence of microtubular protein (8). This binding is proportional to time (Fig. 3), and is linear with the protein content up to $1.2 \mathrm{mg}$ protein/ tube under conditions employed. Determination of the distribution of microtubular (colchicine-binding) protein among subcellular fractions of renal medulla indicated that cytosol $(100,000-g$ supernate) far exceeds all other fractions in its ability to bind $\left[{ }^{3} \mathrm{H}\right]$ colchicine (Fig. 4 ). If the colchicine-binding activity of cytosol is taken as $100 \%$, the ability of particulate fractions to bind $\left[{ }^{3} \mathrm{H}\right]$ colchicine was less than $6 \%$, plasma membranes being the least active. Colchicine-binding protein in renal medullary cytosol showed some characteristic properties described for analogous protein from brain (19): the colchicine-binding activity was labile after prolonged incubation of $0^{\circ} \mathrm{C}$ or after short incubation at $60^{\circ} \mathrm{C}$, and 
TABLE IV

Effects of Colchicine and Vinblastine on Adenylate Cyclase and Cyclic AMP Phosphodiesterase

\begin{tabular}{cc}
\hline \multirow{2}{*}{ Condition } & Activity \\
\cline { 2 - 3 } & Basal activity $\quad$ with $2 \times 10^{-6} \mathrm{M}$ [8-arginine]-vasopressin \\
\hline pmol/min per $\mathrm{mg}$ protein*
\end{tabular}

Adenylate cyclase of renal medullary plasma membranes assayed in presence or absence of colchicine and vinblastine

$\begin{array}{llr}\text { control } & 4.91 \pm 0.22(3) & 38.4 \pm 0.56(3) \\ \text { with } 10^{-5} \mathrm{M} \text { colchicine } & 4.98 \pm 0.33(3) & 42.43 \pm 2.26(3) \\ \text { with } 10^{-5} \mathrm{M} \text { vinblastine } & 4.86 \pm 0.12(3) & 39.11 \pm 2.35(3)\end{array}$

Cyclic AMP phosphodiesterase after preincubation $\ddagger$ with colchicine or vinblastine nmol/min per mg protein*

control

$1.61 \pm 0.11(6)$

Preincubated with colchicine $\quad 1.62 \pm 0.11(6)$

Preincubated with vinblastine $\quad 1.58 \pm 0.16(6)$

* Mean $\pm \mathrm{SE}$; number of experiments in parentheses.

$\ddagger$ Bovine renal medullary cytosol was incubated at $37^{\circ} \mathrm{C}$ in a medium containing $8 \times 10^{-3} \mathrm{M}$ $\mathrm{MgCl}_{2}, 8 \times 10^{-3} \mathrm{M}$ potassium phosphate, and $1 \times 10^{-6} \mathrm{M}$ EDTA ( $p \mathrm{H} \mathrm{6.8).} \mathrm{Concentration}$ of colchicine was $5 \times 10^{-5} \mathrm{M}$, of vinblastine $1.3 \times 10^{-4} \mathrm{M}$. After a 60 -min incubation, tubes were cooled in ice and samples of preparations assayed in triplicate for cyclic AMP phosphodiesterase activity (see Methods).

colchicine-binding protein was completely precipitated from the cytosol by incubation with vinblastine (Table VI).

\section{DISCUSSION}

In our in vivo experiments, two structurally unrelated microtubule-disrupting agents (8) prevented or markedly inhibited the antidiuretic action (decrease in urine volume and increase in Uosm) of exogenous vasopressin. Lumicolchicine, a derivative of colchicine that does not interact with microtubules (22), did not block the antidiuretic response to exogenous vasopressin.

Action of any drug which inhibits the antidiuretic action of vasopressin could be attributed to at least two different mechanisms: (a) interference with the action of vasopressin on cells of distal nephron to increase water permeability and (b) washout of the corticomedullary gradient of solutes. Although our results cannot decide completely between these two possibilities, several features favor the interpretation that colchicine and vinblastine interfered with the cellular action of vasopressin and not primarily by producing medullary solute washout. Since no changes in UVosm occurred, solute washout due to osmotic diuresis is not likely. $\mathrm{UV}_{\mathrm{Na}}$ did not increase (with the exception of a slight transitory increase on day 4 in the presence of colchicine) and this indicates that no major depression of sodium reabsorption (such as occurs after administration of

TABLE V

Effects of Colchicine and Vinblastine on the Protein Kinase

\begin{tabular}{|c|c|c|c|c|}
\hline \multirow[b]{2}{*}{ Condition } & \multicolumn{2}{|c|}{$\begin{array}{c}\text { Endogenous substrate } \\
(150 \mu \mathrm{g} / \text { assay })\end{array}$} & \multicolumn{2}{|c|}{$\begin{array}{l}\text { Histones as substrate } \\
\quad(40 \mu \mathrm{g} / \text { assay })\end{array}$} \\
\hline & Basal & $\begin{array}{c}\text { with } \\
5 \times 10^{-6} \mathrm{M} \\
\text { cyclic AMP }\end{array}$ & Basal & $\begin{array}{c}\text { with } \\
5 \times 10^{-6} \mathrm{M} \\
\text { cyclic AMP }\end{array}$ \\
\hline & \multicolumn{4}{|c|}{ pmol $P_{i} / 1$ mg protein $/ \min$} \\
\hline Control & $0.23 \pm 0.01^{*}(7)$ & $0.84 \pm 0.07$ & $0.54 \pm 0.09$ & $2.25 \pm 0.206(7)$ \\
\hline Preincubated with colchicine & $0.21 \pm 0.02$ & $0.78 \pm 0.03(6)$ & $0.46 \pm 0.04(6)$ & $2.16 \pm 0.65$ \\
\hline Preincubated with vinblastine & $0.21 \pm 0.02$ & $0.79 \pm 0.07(6)$ & $0.44 \pm 0.07(6)$ & $2.21 \pm 0.22$ \\
\hline
\end{tabular}

Preincubation conditions as in Table IV. Activities of enzymes incubated with alkaloids were not significantly different $(P>0.05)$ from controls when evaluated by $t$ test for paired observations.

* Mean \pm SEM; number of experiments in parentheses. 
saluretics) occurred. There was no significant increase in urinary potassium due to administration of colchicine and vinblastine, and excessive gastrointestinal loss of potassium is unlikely since no diarrhea was observed. Also in control experiments, no decrease in serum potassium was observed. These results suggest that the observed unresponsiveness to exogenous vasopressin is not caused by depletion of potassium (23).

A large alteration in glomerular filtration rate (GFR) could produce changes in urine flow and urine concentration. Total creatinine excretion did not change markedly in the course of experiments in either control animals or animals treated with alkaloids, and this observation, in conjunction with finding of normal plasma levels of creatinine at the end of the experiment, indicates that GFR did not change due to the action of drugs or hormone (Tables I and III). It is unlikely that the alkaloids damaged the renal tubules since the excretion of sodium, potassium, and creatinine was unaffected and no glucosurialor proteinuria was detected. Hypercalcemia can inhibit the response to vasopressin (24). In our control experiment, no changes in serum calcium were observed in colchicine-treated rats; Henneman, Montierth, and Nichols reported that colchicine caused hypocalcemia in rats (13). Thus, hypercalcemia is an unlikely explanation for the unresponsiveness to exogenous vasopressin in rats treated with the alkaloids.

The view that colchicine and vinblastine blocked the effect of exogenous vasopressin by interfering with its cellular action on the distal nephron finds further support in reported observations on the toad bladder (6). In that system the tested alkaloids blocked the effect of

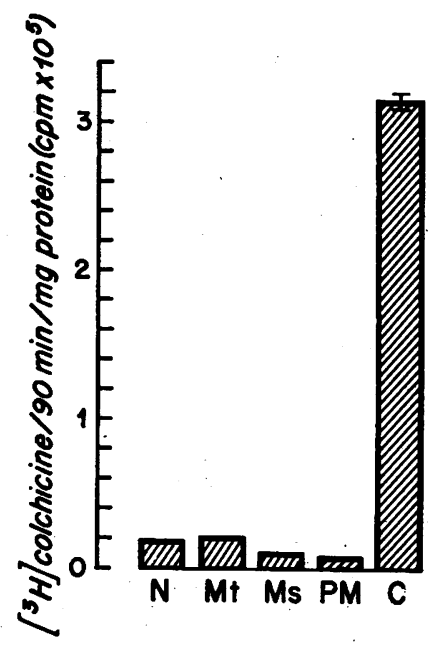

FIGURe 4 Subcellular distribution of $\left[{ }^{3} \mathrm{H}\right]$ colchicine-binding protein in bovine renal medulla. Fractions denoted: $N$ = nuclear $\mathrm{Mt}=$ mitochondria ; $\mathrm{Ms}=$ microsomes; $\mathrm{PM}=$ plasma membranes; $\mathrm{C}=$ cytosol. Values represent means $\pm \mathrm{SE}$ for triplicate determinations.
TABLE VI

Some Properties of Colchicine-Binding Protein of Bovine Renal Medulla

\begin{tabular}{|c|c|}
\hline Condition & {$\left[{ }^{\circ} \mathrm{H}\right]$-colchicine bound } \\
\hline & $c p m \times 10^{2} / \mathrm{mg}$ protein per $90 \mathrm{~min} *$ \\
\hline \multicolumn{2}{|c|}{ Stability of the colchicine-binding protein of renal medullary cytosol } \\
\hline $\begin{array}{l}\text { Cytosol } \\
\text { Cytosol incubated } 5 \mathrm{~min} \text { at } 60^{\circ} \mathrm{C} \\
\text { Cytosol incubated } 15 \mathrm{~min} \text { at } 60^{\circ} \mathrm{C} \\
\text { Cytosol incubated } 24 \mathrm{~h} \text { at } 0^{\circ} \mathrm{C}\end{array}$ & $\begin{array}{r}1,283 \pm 3 \\
197 \pm 5 \\
36 \pm 9 \\
171 \pm 2\end{array}$ \\
\hline \multicolumn{2}{|c|}{$\begin{array}{l}\text { Precipitation of the colchicine-binding activity from the renal medullary } \\
\text { cytosol by vinblastine }\end{array}$} \\
\hline $\begin{array}{l}\text { Cytosol } \\
\text { Vinblastine supernate } \\
\text { Vinblastine precipitate }\end{array}$ & $\begin{array}{c}1,926 \pm 3 \\
266 \pm 14 \\
74,150 \pm 187\end{array}$ \\
\hline
\end{tabular}

* Mean \pm SE.

$¥$ Bovine renal medullary cytosol was incubated in a medium containing $8 \times 10^{-3} \mathrm{M} \mathrm{MgCl}_{2} ; 8 \times 10^{-3} \mathrm{M}$ potassium phosphate, $1.8 \times 10^{-4} \mathrm{M} \mathrm{GTP}$ and $2 \times 10^{-3} \mathrm{M}$ vinblastine sulfate $(\mathrm{pH}=6.8)$ at $0^{\circ} \mathrm{C}$ for $60 \mathrm{~min}$. Precipitate was obtained by centrifugation at $27,000 \mathrm{~g}$ for $60 \mathrm{~min}$ at $0^{\circ} \mathrm{C}$. Concentration of vinblastine in all samples was adjusted to $10^{-4} \mathrm{M}$ and the [ $\left.{ }^{3} \mathrm{H}\right]$ colchicine-binding was assayed as described in Methods. Protein in preparation was precipitated by TCA and vinblastine removed by methanol (35) before protein determination by Lowry's (20) method.

vasopressin on water flow in spite of the fact that the osmotic gradient across the epithelium was artifically maintained. The fact that the colchicine or vinblastine did not inhibit the active sodium transport (basal or stimulated by vasopressin) in the amphibian bladder also suggests, although indirectly, that the tested agents do not interfere with active sodium transport across analogous epithelia of mammalian nephron.

Colchicine and lumicolchicine have been reported to inhibit some membrane transport phenomena in mammalian cells $(10)$. In the present studies colchicine inhibited the antidiuretic response to exogenous vasopressin while lumicolchicine had no effect. Since only colchicine and not lumicolchicine can interact with microtubular protein both in vivo and in vitro (22), the vasopressin-blocking effect of colchicine is probably related to its interaction with microtubular protein rather than to its direct effect on membranes in renal cells.

The inhibition of antidiuretic action of vasopressin was not complete, since urine osmolality remained always above osmolality of plasma. This feature also is similar to the findings in toad bladder (6). Although the alkaloids clearly prevented the response to exogenous vasopressin, they apparently did not reverse the effect of endogenous vasopressin under our experimental conditions (urine osmolality on day 3 remained higher than serum osmolality; Tables I and III). A possible explanation for this finding may be related to the mechanism by which these alkaloids interfere with microtubules in this tissue. Microtubule-disrupting effects of colchicine and vinblastine may be due to their ability to prevent polymerization of microtubular subunits. Several

Microtubules in the Action of Vasopressin 259 
studies indicate that monomers and polymers of microtubular protein exist in the cell in dynamic equilibrium (8). It has been demonstrated that these alkaloids bind to the microtubular protein subunit (8), but do not interact with polymerized microtubules $(25,26)$. In addition, colchicine prevents the polymerization of microtubular protein $(27,28)$. If the cellular action of vasopressin promotes polymerization of microtubular protein, colchicine and vinblastine may prevent the action of vasopressin by binding to microtubular protein, thereby interfering with microtubule formation. On the other hand, under our experimental conditions the alkaloids may not have interacted with existing polymerized microtubules, and hence could not reverse the effect of endogenous vasopressin.

Since microtubule-disrupting alkaloids inhibited the response to both exogenous vasopressin and cyclic AMP in the isolated toad bladder, the authors concluded that the alkaloids acted on a site distal to cyclic AMP generation (6). Renal response to exogenous cyclic AMP is difficult to evaluate in the whole organism because exogenous cyclic AMP or its derivatives could possibly mimic not only the action of vasopressin on distal tubules but also of a host of other hormones, all mediated by cyclic AMP. Administration of cyclic AMP or its derivatives to the whole organism produced various effects, and findings varied from antidiuresis to no response to a clearly diuretic response (29-32).

In view of this, and also because colchicine and especially vinblastine were reported to influence enzymes of cyclic AMP metabolism from organs other than the kidney (33), we tested the effects of these two drugs on the adenylate cyclase and cyclic AMP phosphodiesterase from renal medulla in vitro. The known components of the cellular action of vasopressin are qualitatively similar in all mammalian renal medulla examined (15), and bovine renal medulla was chosen for our in vitro studies because it was available in sufficient quantities for subcellular preparations.

Lack of inhibition of renal medullary adenylate cyclase and cyclic AMP phosphodiesterase (Table IV) supports the view that neither drug interferes with the cyclic AMP metabolism itself in this tissue. As mentioned above, a possible role of cyclic AMP action in the membrane permeability regulation currently under investigation is the action involving phosphorylation of membrane proteins $(4,5)$. Reports differ whether microtubular protein contains cyclic AMP-stimulated protein kinase or not $(8,34)$; findings showing that microtubule protein can serve as a substrate for the phosphorylation, at least in the brain, appear to be more consistent $(8,34,35)$. In bovine renal medulla, the protein kinase activity ${ }^{3}$ as well as the colchicine-binding protein (Fig. 4) are con-

${ }^{3}$ L. D. Barnes and T. P. Dousa. Unpublished results. tained mostly in cytosol. Colchicine or vinblastine did not produce appreciable inhibition of cytosolic protein kinase in our experiments. This may indicate that colchicine or vinblastine do not act by inhibition of protein kinase in this tissue. Protein kinase activity in the crude unfractioned cytosol may conceivably represent a mixture of enzymes differing in some properties, such as relative substrate specificity and others (36). Therefore, the possibility still remains that colchicine and vinblastine might act on some specific protein kinase that represents a very small fraction of the total protein kinase activity in the crude cytosol or that the inhibition is apparent only if the enzyme acts on a natural protein substrate that has not yet been identified.

The ultimate site of vasopressin action appears to be the change of water permeability of lumenal plasma membranes (37). According to some reports, appreciable amounts of microtubular protein were found to be tightly associated with cellular membranes $(38,39)$. In renal medulla, microtubular protein, estimated by $\left[{ }^{3} \mathrm{H}\right]$ colchicine binding $(14,40)$, was found almost exclusively in cytosol (Fig. 4), a finding similar to that described for the tissue culture cells (40). No major portion of colchicine-binding protein was found to be tightly associated with plasma membranes or other membrane particles in our in vitro system. The minimal amount of colchicinebinding activity detected in plasma membranes (less than $4 \%$ of the activity in cytosol) may well be a contamination by cytosolic proteins. Nevertheless, we do not exclude the possibility, suggested by the morphological findings in other cell systems (41), that cytoplasmic microtubules may be in contact and act on the plasma membrane in the intact cells.

The role of cytoplasmic microtubules in the cyclic AMP action to increase water permeability is rather a matter of speculation at the present time. Two major possibilities may be considered. First, cyclic AMP may act directly or indirectly (e.g. via phosphorylation) to change some properties of microtubules (e.g. ability to assemble or turnover rate). Such cyclic AMP-induced change in microtubules may influence the lumenal plasma membrane permeability, e.g. by release of secretion granules $(6,8)$ or by direct change of topographic distribution of membrane proteins (42). The degree of polymerization of microtubules in a submembranal layer of cytoplasm might also conceivably be associated with changes of water permeability and some mechanical properties of lumenal plasma membrane, elicited by vasopressin and cyclic AMP (43).

An alternative possibility is that cyclic AMP does not interact with microtubules at all, but that the function of microtubules in cyclic AMP action is rather a passive or permissive one. Cytoplasmic microtubules may serve as structural elements that hold cyclic AMP-de- 
pendent enzymes (e.g. cyclic AMP-dependent protein kinase or protein phosphatase) acting on membranes in proper localization with their respective substrates (the membrane proteins). Microtubules may also provide a structural basis for compartmentalization of pools of substrates and modulators such as cyclic AMP, ATP, Ca, or $\mathrm{Mg}$ within the cell. In the latter situation, microtubuledissociating alkaloids may not interact and interfere with any of the individual components of cyclic AMP-mediated system (enzymes, membranes), but by disrupting the microtubular framework, they can render this system inoperative in the intact cells.

\section{ACKNOWLEDGMENTS}

We are indebted to Dr. Hosley of Eli Lilly Co., Ltd. for supplies of colchicine and vinblastine sulfate. Dr. Keith E. Holley, Department of Experimental and Anatomical $\mathrm{Pa}$ thology, Mayo Clinic and Foundation kindly performed the morphological examination of kidneys. We thank Carma Jean Fink for secretarial assistance and $\mathrm{Mr}$. Christopher Wilson and Mrs. Yvonne S. F. Hui for expert technical assistance.

This study was supported by U. S. P. H. S. research grant AM-16105 from the National Institute of Arthritis Metabolic and Digestive Diseases, General Research support grant 5 SO1-RR-05530-10, by Grant-in-Aid from the American Heart Association with funds contributed in part by the Minnesota Heart Association and by the Mayo Foundation.

\section{REFERENCES}

1. Orloff, J. S., and J. S. Handler. 1967. The role of adenosine $3^{\prime}, 5^{\prime}$-phosphate in the action of antidiuretic hormone. Am. J. Med. 42: 757-768.

2. Dousa, T. P. 1973. Role of cyclic AMP in the action of antidiuretic hormone. Life Sci. 13: 1033-1043.

3. Jard, S., and F. Bastide. 1970. A cyclic AMP-dependent protein kinase from bladder epithelial cells. Biochem. Biophys. Res. Commun. 39: 559-566.

4. Dousa, T. P., H. Sands, and O. Hechter. 1972. Cyclic AMP-dependent reversible phosphorylation of renal medullary plasma membrane protein. Endocrinology. 91: 757-763.

5. DeLorenzo, R. J., K. G. Walton, P. F. Curran, and P. Greengard. 1973. Regulation of phosphorylation of a specific protein in toad-bladder membrane by antidiuretic hormone and cyclic AMP and its possible relationship to membrane permeability changes. Proc. Natl. Acad. Sci. U.S. A. 70: 880-884

6. Taylor, A., M. Mamelak, E. Raven, and R. Maffly. 1973. Vasopressin: possible role of microtubules and microfilaments in its action. Science (Wash. D. C.). $181: 347-349$.

7. Ericsson, J. L. E., and B. Trump. 1969. Electron microscopy of the uriniferous tubules. In The Kidney. C. Rouiller and A. F. Muller, editors. Academic Press, Inc., New York. 413.

8. Olmsted, J. B., and G. G. Borisy. 1973. Microtubules. Am. Rev. Biochem. 42: 507-540.

9. Harrington, A. R., and H. Valtin. 1968. Impaired urinary concentration after vasopressin and its gradual correction in hypothalamic diabetes insipidus. J. Clin. Invest. 47 : 502-510.
10. Mizel, S. B., and L. Wilson. 1972. Nucleoside transport in mammalian cells. Inhibition by colchicine. Biochemistry. $11: 2573-2578$.

11. Andriole, V. T., and F. H. Epstein. 1965. Prevention of pyelonephritis by water diuresis: evidence for the role of medullary hypertonicity in promoting renal infection. J. Clin. Invest. 44: 73-79.

12. Levinson, S. A., and R. P. MacFate. 1969. Clinical Laboratory Diagnosis. Lea \& Febiger, Philadelphia. 7 th edition. 413.

13. Henneman, D. H., E. Montierth, and G. Nichols, Jr. 1973. Colchicine blockade of parathyroid (PTH) effects on collagen and calcium metabolism in bone. Abstract 55th Annual Meeting of the Endocrine Society. 162.

14. Weisenberg, R. C., G. G. Borisy, and E. W. Taylor. 1968. The colchicine-binding protein of mammalian brain and its relation to microtubules. Biochemistry. 7: 4466-4483.

15. Dousa, T. P., O. Hechter, I. L. Schwartz, and R. Walter. 1971. Neurohypophyseal hormone-responsive adenylate cyclase from mammalian kidney. Proc. Natl. Acad. Sci. U. S. A. 68: 1693-1697.

16. McKenzie, S. G., and H. P. Bär. 1973. On the mechanism of adenyl cyclase inhibition by adenosine. Can. J. Physiol. Pharmacol. 51 : 190-196.

17. Dousa, T. P., and C. F. Code. 1974. Effect of histamine and its methyl derivatives on cyclic AMP metabolism in gastric mucosa and its blockade by an $\mathrm{H}_{2}$ receptor antagonist. J. Clin. Invest. 53: 334-337.

18. Fitzpatrick, D. F., C. R. Davenport, L. Forte, and E. J. Landon. 1969. Characterization of plasma membrane proteins in mammalian kidney. I. Preparation of membrane fraction and separation of the protein. J. Biol. Chem. 244 : 3561-3569.

19. Wilson, L. 1970. Properties of colchicine binding protein from chick embryo brain: interactions with Vinca alkaloids and podophyllotoxin. Biochemistry. 9: 49995007.

20. Lowry, O. H., N. J. Rosenbrough, A. L. Farr, and R. J. Randall. 1951. Protein assessment with the Folin phenol reagent. J. Biol. Chem. 193: 265-275.

21. Hill, A. B. 1961. Principle of Medical Statistics. Oxford University Press, Inc., New York. Seventh edition. 146.

22. Wilson, L., and M. Friedkin. 1967. The biochemical events of mitosis. II. The in vivo and in vitro binding of colchicine in grasshopper embryos and its possible relation to inhibition of mitosis. Biochemistry. 6: 31263135.

23. Relman, A. S., and W. B. Schwartz. 1958. The kidney in potassium depletion. Am. J. Med. 24: 764-773.

24. Manitius, A., H. Leviton, D. Beck, and F. H. Epstein. 1960. On the mechanism of impairment of renal concentrating ability in hypercalcemia. J. Clin. Invest. 39: 693-697.

25. McLean, W. G., and P. Keen. 1973. Colchicine-binding activity and neurotubule integrity in a rat sympathetic ganglion. Exp. Cell Res. 80: 345-353.

26. Filner, P., and O. Behnke. 1973. Stabilization and isolation of brain microtubules with glycerol and dimethylsulfoxide. J. Cell Biol. 59: 99a. (Abstr.).

27. Borisy, G. G., J. B. Olmsted, and R. A. Klugman. 1972. In vitro aggregation of cytoplasmic microtubule subunits. Proc. Natl. Acad. Sci. U. S. A. 69: 2890-2894.

Microtubules in the Action of Vasopressin 
28. Shelanski, M. L., F. Gaskin, and C. R. Cantor. 1973. Microtubule assembly in the absence of added nucleotides. Proc. Natl. Acad. Sci. U. S. A. 70: 765-768.

29. Abe, Y., S. Morimoto, J. Ueda, and K. Yamamoto. 1968. Effects of dibutyl cyclic $3^{\prime}, 5^{\prime}$-adenosine monophosphate on the renal function. Jap. J. Pharmacol. 18: 271-273.

30. Martinez-Maldonado, M., G. Eknoyan, and W. N. Suki. 1971. Natriuretic effects of vasopressin and cyclic AMP: possible site of action in the nephron. Am. J. Physiol. 220 : 2013-2020.

31. Alexander, C. S. 1965. The effect of $3^{\prime}, 5^{\prime}$-cyclic AMP and other nucleotides on urine flow and hemodynamics in the rat. J. Clin. Invest. 44: 1025. (Abstr.).

32. Levine, R. A. 1968. Antidiuretic responses to exogenous adenosine $3^{\prime}, 5^{\prime}$-monophosphate in man. Clin. Sci. 34: 253-260.

33. Weinryb, I., M. Chasin, C. A. Free, D. W. Harris, H. Goldenberg, I. M. Michel, V. S. Paik, M. Phillips. S. Samamiego, and S. M. Hess. 1972. Effects of therapeutic agents on cyclic AMP metabolism in vitro. $J$. Pharmacol. Sci. 61: 1556-1567.

34. Murray, A. W., and M. Froscio. 1971. Cyclic AMPdependent phosphorylation of microtubular protein by protein kinases. Proc. Aust. Biochem. Soc. 4: 8.

35. Reddington, M., and J. R. Lagnado. 1973. Phosphorylation of colchicine-binding ('Microtubular') protein in respiring slices of guinea pig cerebral cortex. FEBS (Fed. Eur. Biochem. Soc.). Lett. 30: 188-194.

36. Krebs, E. G. 1972. Protein kinases. Curr. Top. Cell. Regul. 5 : 99-133.

37. Grantham, J. J. 1971. Mode of water transport in mammalian renal collecting tubules. Fed. Proc. 30: 14 21.

38. Lagnado, J. R., C. Lyons, and G. Wickremasinghe. 1971. The subcellular distribution of colchicine-binding ('Microtubule Protein') in rat brain. FEBS (Fed. Eur. Biochem. Soc.) Lett. 15: 254-260.

39. Feit, M., S. H. Barondes, G. Dutton, and M. L. Shelanski. 1970. Distribution of colchicine binding activity and turnover of microtubule protein in brain. Fed. Proc. 29: 252. (Abstr.).

40. Borisy, G. G., and E. W. Taylor. 1967. The mechanism of action of colchicine. Binding of colchicine $-{ }^{8} \mathrm{H}$ to cellular protein. J. Cell Biol. 34: 525-533.

41. Silveria, M., and K. R. Porter. 1964. The spermatosis of flatworms and their microtubular system. Protoplasma. 59 : 240-265.

42. Ukena, T. E., and R. D. Berlin. 1972. Effects of colchicine and vinblastine on the topographical separation of membrane functions. J. Exp. Med. 136: 1-7.

43. Grantham, J. J. 1970. Vasopressin: effect on deformability of urinary surface of collecting duct cells. Science (Wash., D. C.). 168: 1093-1095. 